\title{
The Study of Misconceptions on Motion's Concept and Remediate Using Real Experiment Video Analysis
}

\author{
Fatni Mufit \\ Faculty of Mathematics and Science, Padang State University \\ fatni.mufit@gmail.com
}

\begin{abstract}
In physics, the concept of motion studied in the mechanics that studies the movement of an object. Many studies have revealed that the concepts of motion are common misconceptions, either by students and teachers. In general, misconception occurs because prior knowledge obtained by the students when interacting with nature before they enter school institutions. Misconceptions tend to be resistant until they are graduate if not done remediation through real experience. This study aims to analyze student misconceptions about the motions and provide solutions with real experimental video analysis. The method used is a survey and study of literature. Data were obtained from standard test FCI (Force Concept Inventory) with the reasons of answers and semester middle test. Seacrhing national and international journals and conducted workshops to explain the benefit of video analysis in real experiments in an effort to remediate misconceptions. The results of this study explains misconceptions occur in the first year students, especially in the matter of the motion. Students can't relate between the concepts of motion with the equation that explains the concept. Real experimental video analysis is required to remediate the student misconceptions about motion through Tracker program. The real experiment provides a real experience for students to conduct trials like a scientist. Video analysis through the Tracker program guided the students in analyzing each component of motion in detail, such as displacement, velocity, acceleration, energy, and momentum and relate it to the equation. The combination of visualization video and graphical analysis generated on every process of motion can enhance the understanding of the concept and is expected to remediate misconceptions students.
\end{abstract}

Keywords: Misconception, Concept of Motion, Real Experiment, Video Analisys, Tracker.

\section{Introduction}

Mechanics is the study of physics that studies the motion of an object, either motion ignores the force causes of motion (called kinematics), and the motion which takes into account the force of cause of motion (called dynamics). Mechanics is an important study in physics because the underlying physics as according Soedojo (1999) that the mechanics are essentially the beginning and the underlying physics. The concepts of motion in mechanics associated with displacement, velocity, acceleration, force, effort, energy, and momentum. Those concepts are difficult to understand the students because most of the concepts are abstract and often leads to misconceptions. The misconception occurs when students understand the concept of motion based on intuition and common sense they are often incompatible with scientific concepts. Problems also arise when students have trouble reading the graph, analyze the problem and apply them in the equation-equation of motion

The first-year student misconceptions can affect learning physics in subsequent years. In the first year, students study the basic physics of matter that is discussed in general, which are summarized in the course Fundamental Physics or General Physics. Misconceptions of students in the course Fundamental Physics will cause difficulties for students in understanding the physics in advanced courses. Additionally, misconceptions by student teachers can pass on to their students misconception them later when they become teachers.

Results of research Mufit (2016) against the first-year students who have taken the course of General Physics, it was found that the understanding of the concepts of physics students is low $(\leq 50 \%)$ and occurred misconceptions related to the discussion: (1) the force on the vertical motion, (2) the force on circular motion, (3) the resultant force and the velocity vector, (4) force on the parabolic motion, (5) the force on the simple pendulum motion. The results of the research also revealed that the majority of these students $(81 \%)$ find it difficult to solve the problems of physics even though they understand the concept of topics related to the problem. Most students (47\%) felt that the equations of physics do not support their ideas in understanding concepts of physics equations required only for a matter of course.

Suspected causes trouble occurs student and misconceptions in understanding of physics concepts is learning that do not yet fully centered on students, especially in terms of involving students actively construct the concept, in particular the concepts of motion. Motion concepts such as force, work and energy, in general, has been conceived as one of the students as they interact with the environment before they enter the institution. This condition will continue if the learning physics lectures and discussions dominated activity, and only a small portion experimental activities that involve students in the 
invention concept. Experiments were done still tends to be practical cookbook, and has not challenged the students to think deeply in finding and constructing the physics concept of motion. In general practice activities that have been conducted so far have not provided a solution to the problems of student misconceptions.

The solution to increase understanding of physics concepts and remediate misconceptions about motion is a activity real experiment video analysis. This study aims to reveal student misconceptions in particular on the concept of motion, as well as effort to remediate misconceptions about the real experiment motion through video analysis.

\section{Methods}

This study is a survey about student misconceptions in the concept of motion in the course of General Physics. The study also supported by literature study of various journals studies on misconceptions concept of motion by secondary school students, high school and college students. The results of the activities in the workshop on video analysis Real experiment also become a reference writing this paper as an effort to remediate misconceptions. In addition, the results of the international journal of the real experiment video analysis, especially Tracker program will also enrich the study of remediation misconceptions.

\section{Result and Discussions}

\subsection{Misconception}

Ormrod (2008) defines misconceptions as 'trust not in accordance with generally accepted explanation and proved valid about a phenomenon or event'. Meanwhile, Fowler, 1987 (in Suparno, 2013) explains the misconceptions in more detail as the understanding is not accurate concept, the use of the wrong concept, classification examples wrong, chaos concepts are different, and the hierarchical relationship concepts which is not a true physics, misconceptions understood as physics concepts that are not in accordance with the scientific concept as proposed by scientists.

Other terms of the misconceptions is the alternative conception, alternative framework, intuitions, and naive theory, the pupil's idea, and common sense theory. In general, modern researchers prefer the use of the term 'alternative concepts' than 'misconceptions', on the grounds (1) an alternative concept to demonstrate experience constructed by the learners themselves, (2) to reward the intellectual to students who have an idea / ideas , (3) the concept of reasonable alternatives in general contextual and useful to explain some of the problems being faced by learners (Wandersee, et al. 1994 in Suparno, 2013). So the use of the term alternative concept is an appreciation of the idea / notion of students as a result of their own construction interact with nature. However, alternative concepts or misconceptions need to be remediated so that the concept that belongs to the student in accordance with the scientific concept.

Learning occurs when students connect prior knowledge to new knowledge. In constructing new knowledge, students often construct new knowledge is not intact due to their limited capacities or because the idea has been mixed with other ideas that they experience in everyday life. This leads to misconceptions in learning, as Meyer, 1993 (in Liang, 2016) states that when the relationship between prior knowledge and new knowledge is not successful, then the misconceptions may occur.

\subsubsection{Misconception of motionn's concept}

Many studies have revealed misconceptions in physics, especially mechanics. Wandersee, Mintzes, and Novak, 1994 (in Suparno, 2013) states, from 700 studies misconceptions in physics, there are 300 who studied mechanics. The phenomenon of misconceptions occur almost at every level of education, even by Wilardjo (2009), although the quantity of students who have misconceptions tend to decrease with the increase of their age, and the higher the level of their education, but most of them still have misconceptions to college even after being bachelor.

Isnaini (2015) explains that the misconception of the most widely experienced by students on the concept of motion is: "(1) In the stationary objects resultant force is not zero (2) the average velocity is equal to the average speed, (3) can not distinguish between acceleration and velocity, (4) the normal force is always equal to gravity and always a straight line, (5) on a stationary object no force anything done ". The misconception mechanics is also experienced by high school teachers (Wahyudi, 2013), who found misconceptions on teacher to the concept of vertical motion, parabolic motion, circular motion, work and energy, as well as objects equilibrium.

Taufiq (2012) reported the identification of misconceptions are quite high by physical education students in the sixth semester, and his mistake was not on mathematical calculations but also college students have misconceptions related to the concept of styles with different levels. Based on the results of intensive interviews revealed that the cause of the misconception that experienced by students on the concept of style is the fault of the language, film show, thinking ability, family background, parallel conceptions and misconceptions beginning students.

Meanwhile, misconceptions mechanics at the high school level was also revealed through research Masril (2012), which explains that high school students experiencing misconceptions about the kinematics of rectilinear motion of $32.50 \%$, dynamics of rectilinear motion of $47.50 \%$, blend motion $50.74 \%$, uniform circular motion of $48.94 \%$, friction of $40.08 \%$, gravity of $53.33 \%$, effort and energy of $51.82 \%$, as well as impulse, momentum and collisions of $48.61 \%$. Students also had difficulty reading the graph associated with the concept of motion as velocity versus time graph in the vertical motion (ma'rifa, 2016). Hasim research results, (2011) also found that misconceptions about the motion experienced by middle school students. The concept most experienced misconceptions is the concept of gravitational influence on the velocity of the object in motion free fall $(84 \%)$. Student misconception that 'heavier objects fall faster than lighter objects' is also found in the study Tayubi (2005). Some results of these studies indicate misconceptions about the concept of motion experienced by secondary school students, high school and college students. Misconceptions include motion kinematics and dynamics, both in straight motion, circular motion or parabolic motion. 


\subsubsection{Remediation of misconception}

Misconceptions need to be remediated, for whatever reason, misconceptions can impede new learning (Kuhn, 2001b; Reiner et. Al., 2000; Rooth \& Anderson, 1998; in Ormrod, 2009). Misconceptions also be resistant, meaning that if not given action to correct misconceptions, the misconceptions can survive in the student until they graduate, even after becoming a teacher. Some research suggests misconceptions in college students (Kabaca, et al. 2011; Taufiq, 2012; Saputri \& Sarwanto, 2012; Suastika, et al. 2015; Saputri \& Nurussaniah, 2015), at the middle school students (Hashim, 2011; Hafizah , 2014), as well as the teacher (Baser, 2006; Holomoan 2008; Pujayanto 2011; Wahyudi \& Mandira, 2013).

In terms, remediation means the act or process of healing (Suharso \& Retnoningsih, 2016). Remediation of misconceptions can be defined as the act or process of healing of misconceptions (errors of concept) that occurred. Learners who have misconceptions need to be given the action that they realized the mistake and construct new concepts scientifically correct. According Pintrich, et al. (In Carin, 1997) the best way to eliminate the misconceptions is to expose and confront the misconceptions directly. Confrontation or face misconceptions need to do more than just teach the facts of science, but must be based on experience and to provide motivation for the change to the learners.

Printrich, et al. (In Carin, 1997) summarizes the four conditions necessary to change the misconceptions students (and teachers), namely:

1) There must be enough dissatisfaction with present beliefs to abandon them.

2) New understandings must be intelligible to students and help them better understand the ideas

3) New conceptions must be plausible, that is they must be meaningfully related to students' existing knowledge organizations.

4) New framework must be fruitful to falicitate further study.

These conditions need to be created for educators to change misconceptions learners through through a variety of learning strategies or models in an effort to remediate misconceptions.

\subsection{Real Experiment Video Analysis}

Real experiment video analysis is an appropriate alternative in overcoming misconceptions and increase understanding of the concept of the student. Not merely a demonstration or computer simulation, the activities of the 'real experiment video analysis', students obviously do experiments like scientists. For example on the movement of free fall (vertical motion), the concept of a common misconception by both students junior high, high school and college students is that heavier objects fall earlier than lighter objects if dropped simultaneously from the same height. Difficult to do experiments to remediate these misconceptions, because the motion is fast, so hard to catch the eye. But through the 'real experiment video analysis', students can test the truth of their misconceptions with the help of video cameras and menanalisis motion of objects in video using Tracker program.

Real experiments conducted by dropping two balls of the same size, but different mass from the same height simultaneously, as shown in Figure 1.

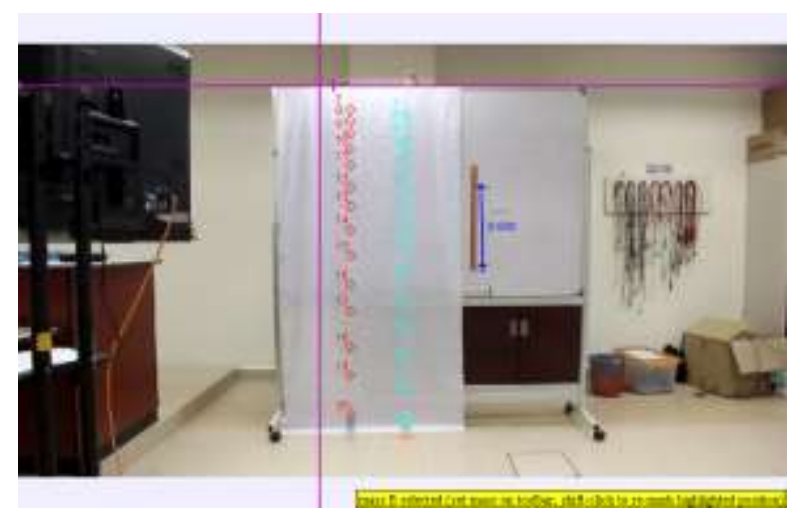

Fig. 1. Tracking Two balls of equal size, a different mass, free fall from the same height simultaneously. (Video contribution Jaafar, 2016 at the workshops)

This experiment was recorded by students through a video camera, with a contrasting set the background that the movement of the ball can be seen clearly. Then students use the program analyzes video tracker to see the traces of balls fall within a certain time interval. Through this analysis students can actively plot the graph of displacement, velocity, acceleration, and energy, according to tracking the ball at every stage movements.

\subsubsection{Program Tracker}

Tracker program has easy steps in analyzing the motion of video recordings. The steps in analyzing the video are: a) to enter the video recordings in the program Tracker, b) determine the mass of the object, c) Determine the coordinates xy axis as the frame of reference of a moving object, d) Determining the scale of distance or displacement of objects. e) Track the motion of objects within a certain time interval, f) Plot the graph is needed.

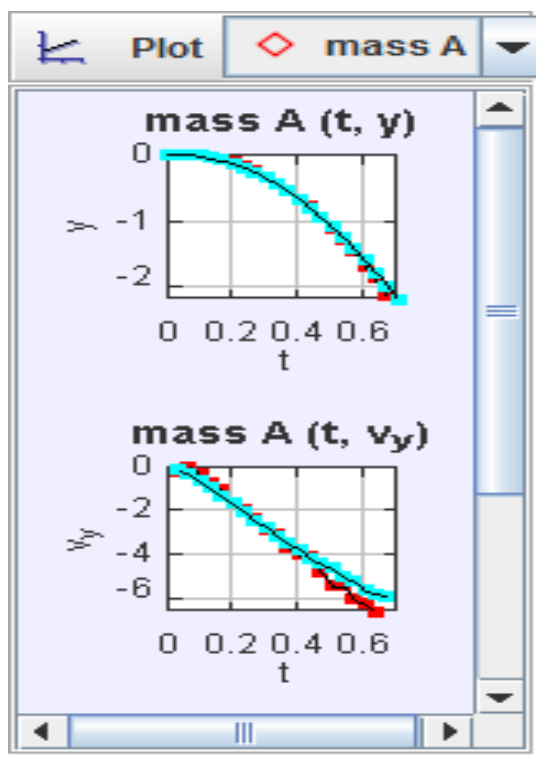

Fig. 2. Displacement and velocity graphs two balls of the same size, different masses, the free fall of the same simultaneously 
The results of video analysis in the form of video footage to track the movement of objects at the same time the motion of objects on each graph desired. The free fall simultaneously (Figure 1), has a displacement and velocity graphs as in Figure 2. In the graph shows that the two balls (whose mass is different) has the same displacement and velocity.

Difficulties and misconceptions students on projectile motion, can be remediated with real experiment as in figure 3 . The ball is thrown to form a certain angle so as to produce a parabolic trajectory. Through Tracker program, students analyze the video footage by tracking the motion of the parabola. Graph tracking the results can be seen in Figure 4. Through the graph in Figure 4, the students gain experience and understanding of the combined uniform rectilinear motion (on the horizontal motion) and a uniformly accelerated motion (on the vertical motion) that form a parabolic motion (projectile motion). This concept is difficult to understand the student without doing real experiments

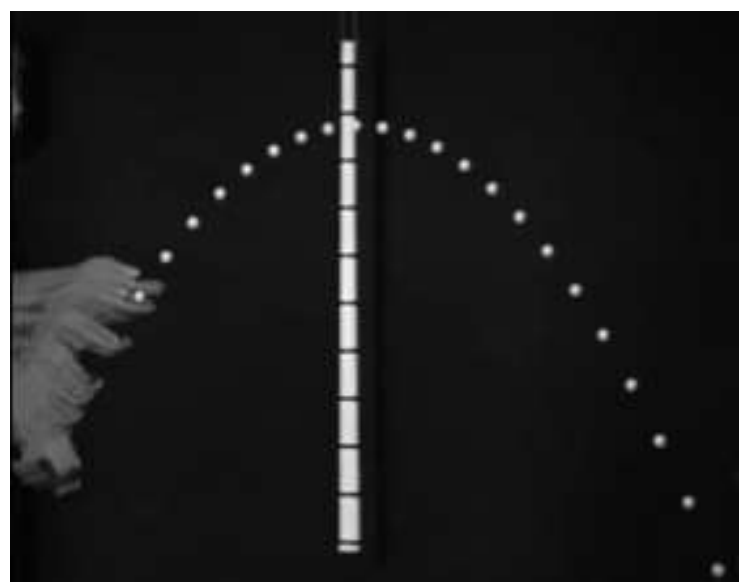

Fig. 3. Rekaman video bola yang dilempar membentuk lintaran peluru atau parabola. (Wee, 2015)

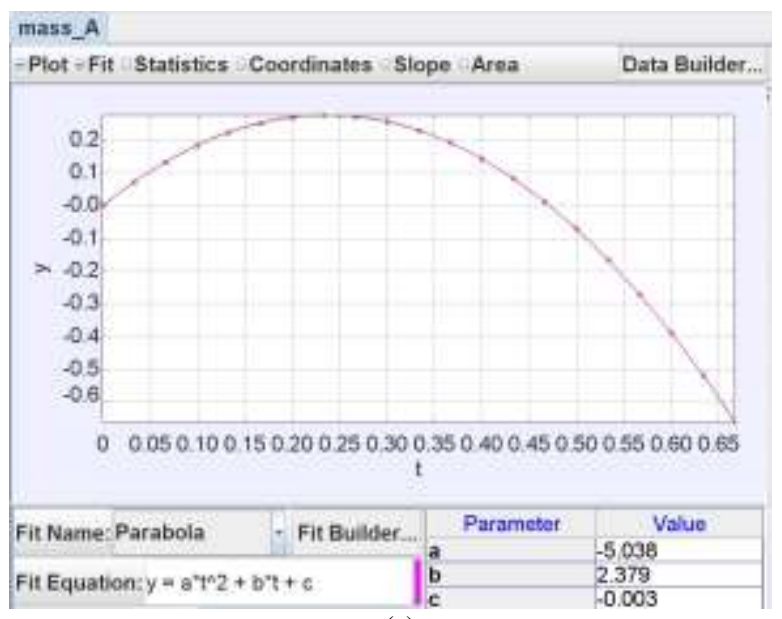

(a)

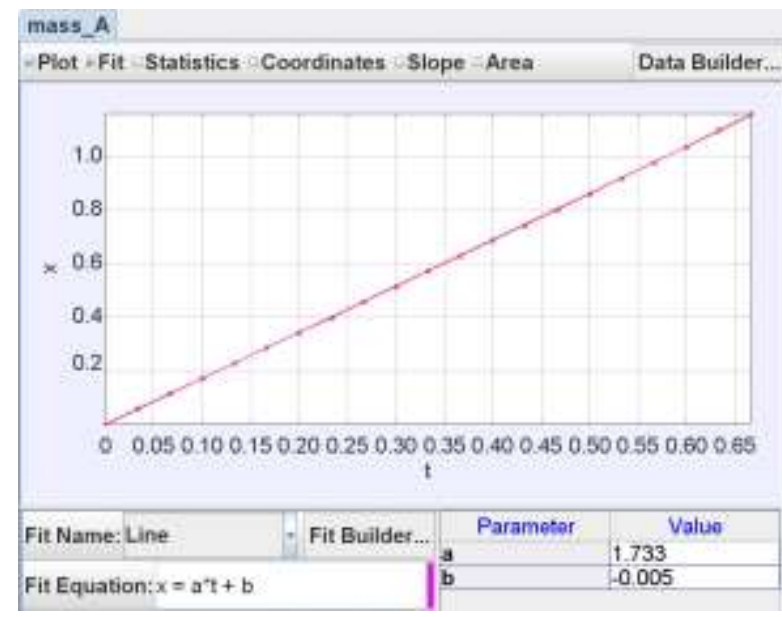

(b)

Fig. 4. Graph object position against time on projectile motion, which indicates that the projectile motion is a combination of vertical motion (a) and horizontal motion (b). (Wee, 2015)

\subsubsection{Remediation of motion's concept}

Another example of real experiments video analysis on the motion of objects on top of the incline can be seen in the Figure. 5.

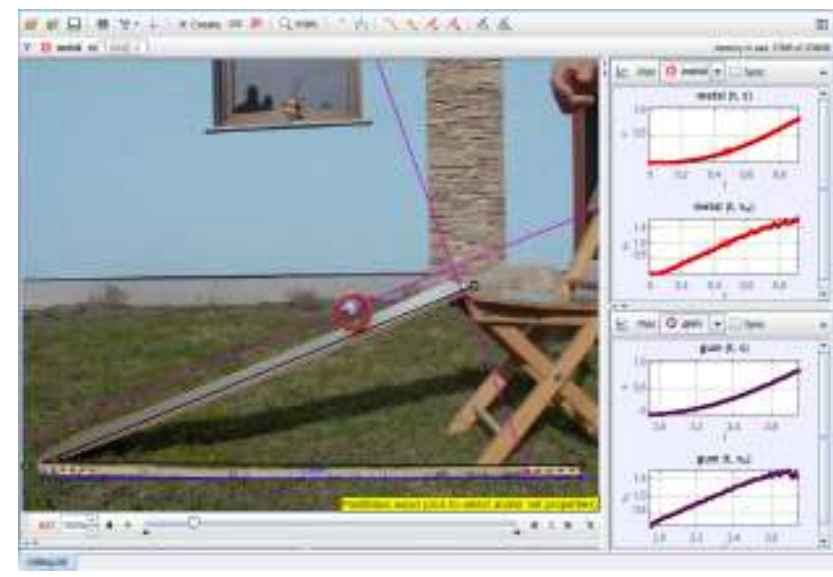

Fig. 5. The video recording motion of the ball on an inclined plane along with displacement and velocity graphs the results of video analysis. (Hockicko, 2012)

Real experiment video analysis on the movement of two colliding objects that can be seen in Figure 6 . The concept of velocity and momentum of the ball can be dianalysis through graph in Figure 7 . The difficulties and misconceptions of students about the concept of momentum can be remediated through this real experiments video analysis. 


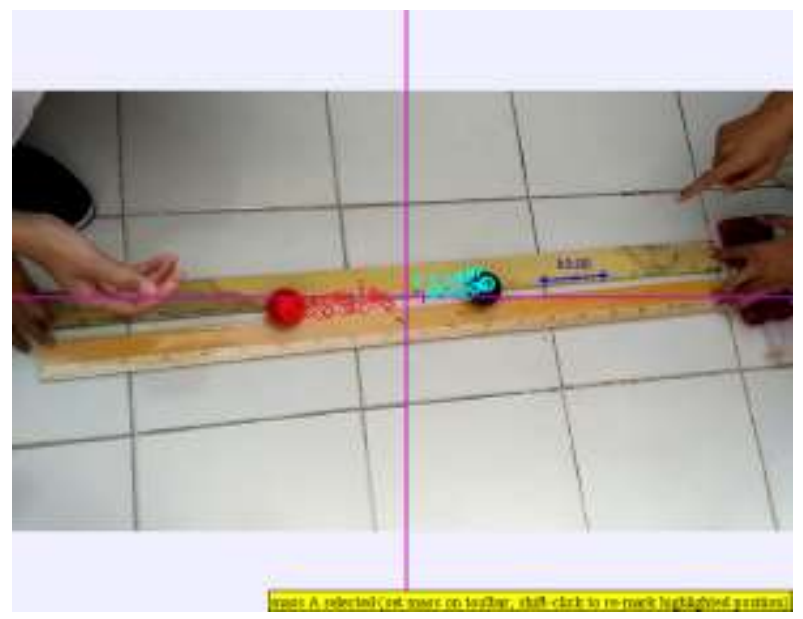

Fig.6. Video recording of the collision two balls

\begin{tabular}{|c|c|c|c|}
\hline 国 Table & $\checkmark$ mass B & & $\Delta$ \\
\hline t & $x$ & $v_{x}$ & $p_{x}$ \\
\hline 0.000 & 16.81 & & \\
\hline 0.033 & 14.07 & -79.00 & -10.66 \\
\hline 0.067 & 11.53 & -76.21 & -10.29 \\
\hline 0.100 & 8.992 & -61.74 & -8.335 \\
\hline 0.133 & 7.428 & -70.42 & -9.507 \\
\hline 0.167 & 4.301 & -49.72 & -6.713 \\
\hline 0.200 & 4.105 & 14.65 & 1.978 \\
\hline 0.233 & 5.278 & 41.02 & 5.538 \\
\hline 0.267 & 6.842 & 23.54 & 3.178 \\
\hline 0.300 & 6.842 & 44.07 & 5.950 \\
\hline 0.333 & 9.774 & 55.60 & 7.506 \\
\hline 0.367 & 10.56 & 29.31 & 3.957 \\
\hline 0.400 & 11.73 & 11.72 & 1.583 \\
\hline 0.433 & 11.34 & 5.882 & 0.794 \\
\hline 0.467 & 12.12 & 23.53 & 3.177 \\
\hline 0.500 & 12.90 & 14.66 & 1.979 \\
\hline 0.533 & 13.10 & 14.63 & 1.976 \\
\hline 0.567 & 13.88 & & \\
\hline
\end{tabular}

Fig.6. Table of position, velocity and momentum are two balls that collide (ball B).

Through the data table (Fig.6) and the graph (Fig.7) generated from the video analysis, students will think deeply in discovering the concepts of motion identical balls that collide. The graph shows the position of the initial position of the ball that moves away, then approached, and back away after colliding. Through the velocity grapht, students will also find that the velocity herded negative value means that the velocity of the ball toward the opposite direction of the original motion. Through the momentum and velocity graphs, students will also find the concept that the velocity of the ball has the same direction as the momentum of the ball. Both the velocity and momentum is a vector quantity. Graph the results of video analysis can also lead students find formulas or equations of physics that describe relationships between concepts. Experiment real video analysis can unify the concept of motion physics students with physics equations that describe the concept.

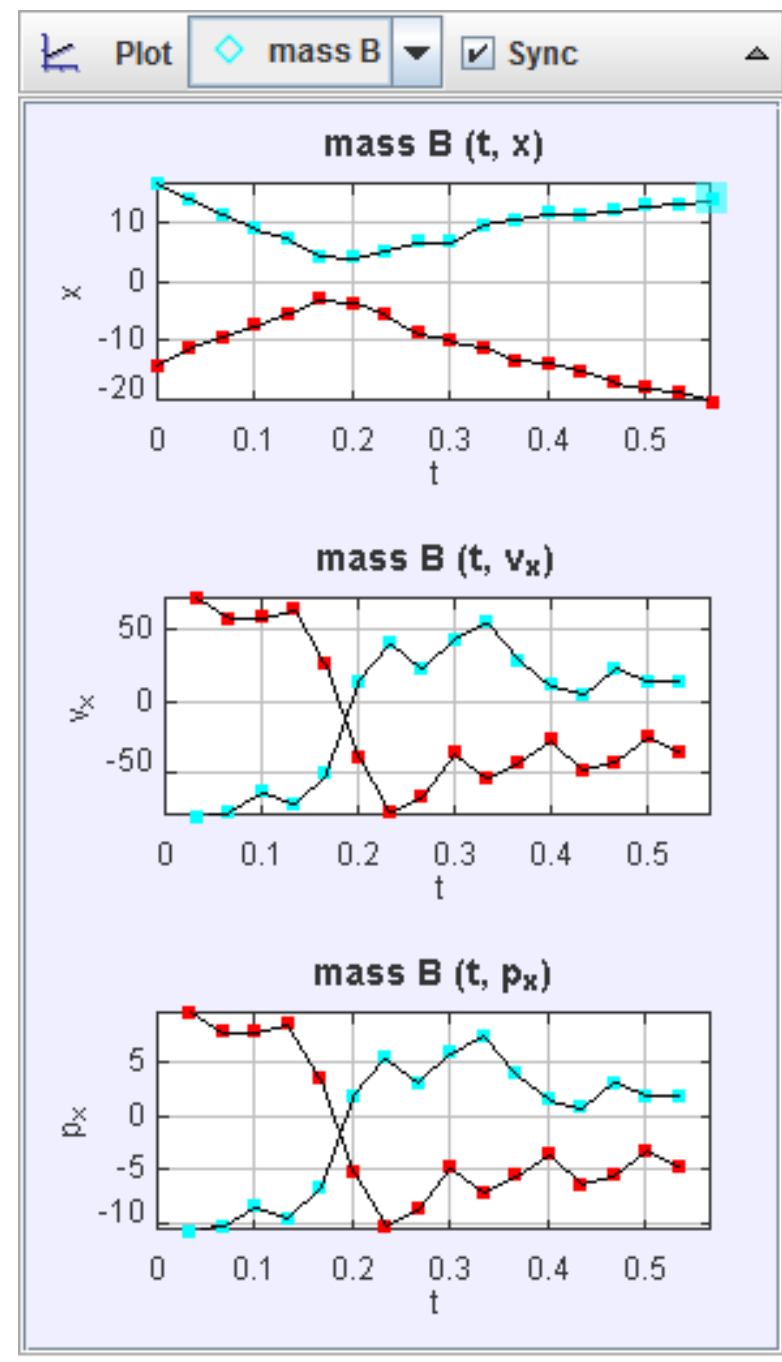

Fig.7. Graph of the position, velocity and momentum are two balls that collide (a blend of ball A and B).

The results of the experiment estate video analysis of the nature of kinetic energy, potential energy and mechanical energy in motion free fall can be seen in Figure 8. This display will improve student understanding of the concept of mechanical energy is constant. The graph (Fig. 9) also explains that the mechanical energy is formed from the sum of kinetic energy and potential energy on collision events

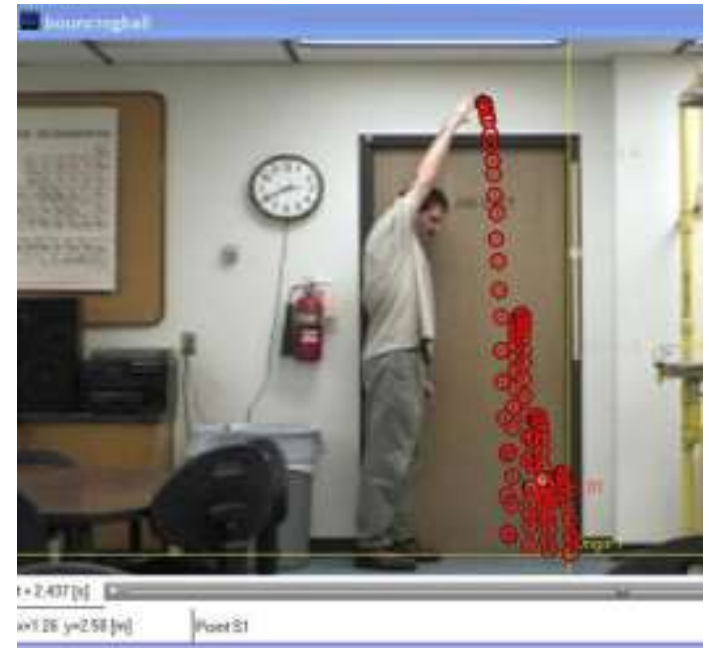

Fig.8. Tracking motion of the ball as many as three of the collision with the floor (Bryan, 2004) 


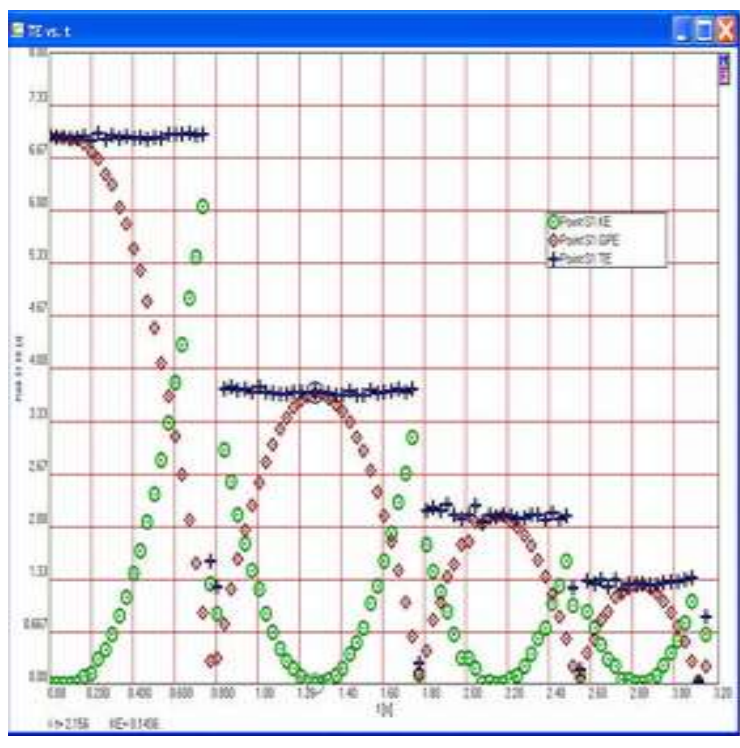

Fig.9. Graphs of kinetic, potential, and total energies of a falling ball which collide with the floor (Bryan, 2004)

Real experimental video analysis corresponds with the nature of science learning that requires students to perform scientific work, scientific attitude and scientific thinking. Known as the scientific method, as was done by the scientists are. Orlich, 1980 (in Rohandi 2009) also provides that a characteristic of science is that science education is more than just a collection of so-called facts. Science is not just a collection of knowledge but also a collection of processes. Learners should be given the opportunity to develop curiosity, so they undergo a process of conceptual change.

More clearly, Santa and Alvermann (in Rohandi, 2009) states that: students need to recognize that the scientific concept contrary to the theory that they have. They need to be reassured that their theory is incomplete, unsuitable or inconsistent with the experimental evidence, and that provides an alternative scientific explanation is more convincing and more helpless. Furthermore, Santa and Alvermann explained that in science learning: students need repetition opportunity in terms of struggling with inconsistency between the idea of which is owned by a scientific explanation, organized way of thinking. ... Create the ideal relationship between the various ideas they have with various scientific concepts. Therefore, learning physics should provide a variety of experiences and facilitate students perform a variety of scientific searches, be aware of their misconceptions and find the concept of physics scientifically correct.

Many scientific research also revealed that learning science is a constructive process that requires the active participation of students, and teachers must actively find ways to understand students' conceptions, suggested alternative conception, stimulates astonishment among students and develop tasks classes that lead to construction of knowledge (Dahar, 2011). This means that students must build their own knowledge in his head and teachers play provides convenience by providing opportunities for students to find and implement their own ideas, and remediate misconceptions in the learning process.

Real Experiment video analysis is the appropriate learning to improve student understanding of concepts and remediate misconceptions, because through this activity, students are directly involved finding the correct scientific concepts. As according Wee (2015) found Video modeling pedagogy is suitable for active and deep learning because the students can be said to be predicting by keying certain values, observing by comparing the real data with the current proposed model. But it also found that comparison of the traditional teaching methods with the methods of video analysis using the program Tracker presented in this contribution has revealed that the interactive methods (Hockicko, 2012). There are three important advantages of video analysis over probes and sensors (Bryan, 2004): 1. Video analysis allows for study of two -dimensional motion, such as revolving objects or projectiles. 2. More than one object can be analyzed in any video, which can lead to detailed comparisons of multiple objects that are in the same system. 3. Video analysis can be performed without all of the cumbersome wires and sensors associated with MBLs.

The real experiment provides a real experience for students to conduct trials like a scientist. Video analysis through the Tracker program guided the students in analyzing each component of motion in detail, such as displacement, velocity, acceleration, energy, and momentum and relate it to the equation. The combination of visualization video and graphical analysis generated on every process of motion can enhance the understanding of the concept and is expected to remediate misconceptions students.

\section{Conclusion}

Misconceptions about the concept of motion discovered in middle school students, college students and teachers, particularly in the concept of vertical motion, circular motion and projectile motion. Misconceptions on the concept of motion can be remediated using real experiment video analysis. Through real experiment video analysis, students gain real experience of conducting experiments, analyzing the graph and find the equation of motion like a scientist. Learning easier and more fun for students. It is advisable to identify student misconceptions about the concept of motion and perform remediation using real experiment video analysis

\section{Acknowledgement}

Acknowledgment delivered for Prof. Rosly Jaafar (Lecturer at Universiti Pendidikan Sutan Idris (UPSI) Malaysia, as a resource for sharing knowledge about the real experiment video analysis with Program Tracker via workshops in the department of Physics, Science and Math Faculty, Padang State University. Thanks acknowledge the contribution of the two ball fell free video.

\section{References}

Baser, M. 2006. "Fostering conceptual change by cognitive conflict based instruction on student understanding of heat and temperature concepts". Eurasia Journal of Mathematics, Science and Technology Education. 2(2). 96-114. Available: http://www.ejmste.com/022006/d6.pdf.

Bryan, J. (2004). Video analysis software and the investigation of the conservation of mechanical energy. Contemporary Issues in Technology and Teacher Education, 4(3), 284-298. 
Carin, Arthur A. (1997). Teaching Science Through Discovery, Eighth edition. Pearson Prentice Hall: New Jersey, Columbus Ohio.

Dahar, Ratna Wilis. 2011. Teori-Teori Belajar dan Pembelajaran. Jakarta: Erlangga.

Halim, L., Yong, T. K., \& Meerah, T. S. M. (2014). Overcoming Students' Misconceptions on Forces in Equilibrium: An Action Research Study. Creative Education, 5, 1032-1042. Available: http://dx.doi.org/10.4236/ce.2014.511117

Halomoan (2008). Analisis Konsepsi Guru Mata Pelajaran Fisika Madrasah Aliyah terhadap Konsep Gaya pada Benda Diam dan Bergerak. Available: http://sumut.kemenag.go.id/.

Hafizah D, Haris V, Eliwatis. (2014). Analisis Miskonsepsi Siswa Melalui Tes Multiple Choice Menggunakan Certanty of Response Index pada Mata Pelajaran Fisika MAN 1 Bukittinggi. Edusainstika, $1(1): 100-103)$

Hasim W., Nasrul Ihsan (2011). Identifikasi Miskonsepsi Materi Usaha, Gaya, dan Energi dengan Menggunakan CRI (Certanty of Response Index) pada Siswa Kelas VIII SMPN 1 Malangke Barat. JSPF Vol. 7 No.1, April 2011 | ISSN : 1858-330X.

Hockocko, Peter (2012). Attractiveness of Learning Physics by Means of Video Analysis and Modeling Tools. SEFI 40th Annual Conference, 23-26 September 2012, Thessaloniki, Greece.

Isnaini (2015) Identifikasi Miskonsepsi Mahasiswa Fisika Menggunakan Tes Diagnostik pada Mata Kuliah Fisika Dasar Materi Gaya dan Gerak. KONSTAN: Jurnal Fisika dan Pendidikan Fisika. Vol. 1. no.1 hal. 29-31

Kabaca T, Z Karadag, M Aktumen (2011). Misconception, cognitive conflict and conceptual changes in geometry: a case study with preservice teachers. Mevlana International Journal of Education (MIJE) Vol. 1(2), pp.44-55, 30 December, 2011. Dapat ditemukan di http://eujournal.org/index.php/esj/article/download/3914/3705

Liang, S. 2016. "Teaching the concept of limit by using conceptual conflict strategy and Desmos graphing calculator". International Journal of Research in Education and Science (IJRES), 2(1), 35-48.

Masril (2012). Pengembangan Model Pembelajaran Fisika SMA BerbasisGraphic Organizer Melalui Belajar Kooperatif Tipe STAD. Jurnal Penelitian Pembelajaran Fisika 1(2012) 1-7. ISSN: 2252 3014 Februari 2012. Available: http://ejournal.unp.ac.id.

Ma'rifa, H. Kamaluddin dan H. Fihrin (2016). Analisis Pemahaman Konsep Gerak Lurus pada Siswa SMA Negeri di Kota Palu, Jurnal Pendidikan Fisika Tadulako (JPFT) Vol. 4 No. 3, ISSN 23383240

Mufit, Fatni (2016). "A Study about Understanding the Concept of Force and Attitude towards Learning Physics on First-Year Students in the Course of General Physics; as Preliminary Investigation in Development Research". Proceeding of SEA-DR (South East AsiaDesign/Development Research) Conference 2016, International Conference: April, $17^{\text {th }}-18^{\text {th }} 2016$. Universitas Negeri Padang, West Sumatera Indonesia. ISBN: 978-602-19877-5-9. (http://seminar.fmipa.unp.ac.id/seadr16/brosur/Prosiding\%204th\%2 OSEADR\%202016.pdf)

Ormrod. J.E. 2009. Psikologi Pendidikan; alih bahasa Triwibowo. J.S. Jakarta: Erlangga.

Pujayanto (2011). Miskonsepsi IPA (Fisika) pada Guru SD. Jurnal Materi dan Pembelajaran Fisika (JMPF) Vol 1 No 1 (2011) 22-24. Available:http://jurnal.fkip.uns.ac.id/index.php/fisika/article/view/1 856

Rohandi, R .2009. "Memberdayakan Anak Melalui Pendidikan Sains". dalam P.J.Suwarno (Eds). Pendidikan Sains yang Humanistis.(hal: 112-126). Yogyakarta: Kanisius.

Saputri D.F \& C Sarwanto (2012) Penyebab Dan Remediasi Miskonsepsi Gaya Menggunakan Multimedia Dan Modul. Jurnal materi dan pembelajaran fisika vol 2, 2012. ISSN: 2089-6158.

Saputri, D. F \& Nurussaniah. (2015) Penyebab Miskonsepsi Pada Optika Geometris. Prosiding Seminar Nasional Fisika (E-Journal)
SNF2015, VOLUME IV, OKTOBER 2015. Available: http://snfunj.ac.id/kumpulan-prosiding/snf2015/

Soedojo, Peter .1999. Fisika Dasar. Yogyakarta: Andi

Suastika, T Jhoni, T Utami (2015). Penelusuran Miskonsepsi Mahasiswa Tentang Matriks Menggunakan Certainty of Response Index. Prosiding Seminar Nasional Fisika (E-Journal) SNF2015, Volume IV, Oktober 2015. Available: http://snf-unj.ac.id/kumpulanprosiding/snf2015/

Suharso \& Ana Retnoningsih.(2016) Kamus Besar Bahasa Indonesia. Semarang: Widya Karya.

Suparno, Paul (2013). Miskonsepsi dan Perubahan Konsep dalam Pendidikan Fisika. PT. Gramedia Widiasarana Indonesia : Jakarta.

Taufiq, Muhammad (2012). Remediasi Miskonsepsi Mahasiswa Calon Guru Fisika Pada Konsep Gaya Melalui Penerapan Model Siklus Belajar (Learning Cycle) 5E. Jurnal Pendidikan IPA Indonesia JPII no I vol 2 pp. 198-203. Available: http://journal. unnes.ac.id/index.php

Tayubi Y R. (2005) Identifikasi Miskonsepsi Pada Konsep-Konsep Fisika Menggunakan Certainty of Response Index (CRI). Mimbar Pendidikan No. 3/XXIV/2005

Wahyudi, I \& N Maharta ( 2013) Pemahaman Konsep Dan Miskonsepsi Fisika Pada Guru Fisika SMA RSBI Di Bandar Lampung. Jurnal Pendidikan MIPA, Volume 14, Nomor 1, April 2013. Available: http://download.portalgaruda.org/

Wee, Loo Kang, et al. (2015). Using Tracker as a Pedagogical Tool for Understanding Projectile Motion. Available : http://arxiv.org/pdf/ 1206.6489.pdf

Wilardjo, Liek .2009. "Secercah Pandangan tentang Pengajaran Sains". dalam P.J.Suwarno (Eds). Pendidikan Sains yang Humanistis.(hal 50-94). Yogyakarta: Kanisius. 